University of Wollongong

Research Online

Faculty of Engineering - Papers (Archive)

Faculty of Engineering and Information

Sciences

2006

\title{
A simple means to immobilize enzyme into conducting polymers via entrapment
}

Jun Chen

University of Wollongong, junc@uow.edu.au

B. Winther-Jensen

University of Wollongong, bjornw@uow.edu.au

C. Lynam

University of Wollongong, lynam@uow.edu.au

O Ngamna

University of Wollongong

S. Moulton

University of Wollongong, smoulton@uow.edu.au

See next page for additional authors

Follow this and additional works at: https://ro.uow.edu.au/engpapers

Part of the Engineering Commons

https://ro.uow.edu.au/engpapers/121

\section{Recommended Citation}

Chen, Jun; Winther-Jensen, B.; Lynam, C.; Ngamna, O; Moulton, S.; Zhang, W.; and Wallace, G G.: A simple means to immobilize enzyme into conducting polymers via entrapment 2006.

https://ro.uow.edu.au/engpapers/121

Research Online is the open access institutional repository for the University of Wollongong. For further information contact the UOW Library: research-pubs@uow.edu.au 


\section{Authors}

Jun Chen, B. Winther-Jensen, C. Lynam, O Ngamna, S. Moulton, W. Zhang, and G G. Wallace 


\title{
A Simple Means to Immobilize Enzyme into Conducting Polymers via Entrapment
}

\author{
Jun Chen, ${ }^{*, z}$ Bjørn Winther-Jensen, Carol Lynam, Orawan Ngamna, \\ Simon Moulton, Weimin Zhang, and Gordon G. Wallace
}

University of Wollongong, Australian Research Council Centre of Excellence for Electromaterials Science, Intelligent Polymer Research Institute, Wollongong, New South Wales 2522, Australia

Poly(3,4-ethylenedioxy thiophene) (PEDT), obtained by chemical vapor phase polymerization can shrink to $5 \%$ of its original thickness during a washing step. This phenomenon was exploited to immobilize the active enzyme, horseradish peroxidase (HRP), into PEDT films by rinsing with an ethanol solution containing HRP. The use of the PEDT-HRP as an amperometric biosensor was demonstrated by sensing $5 \mathrm{mM} \mathrm{H}_{2} \mathrm{O}_{2}$ in phosphate buffered saline solution with a sensitivity of $190 \mu \mathrm{A} \mathrm{cm}^{-2}$. The stability of the immobilization of HRP into the "stuffed" PEDT matrix was also characterized by repeated amperometric detection and scanning electron microscopy mapping images obtained before and after exposure to $\mathrm{H}_{2} \mathrm{O}_{2}$. (c) 2006 The Electrochemical Society. [DOI: 10.1149/1.2201306] All rights reserved.

Manuscript submitted March 10, 2006; revised manuscript received March 28, 2006. Available electronically May 19, 2006.

One of the simplest methods of immobilizing biomolecules on polymer surfaces is adsorption. ${ }^{1}$ This includes both physical adsorption and electrochemical adsorption techniques. The latter is achieved by applying a potential to the polymer electrode surface, which enhances electrostatic interactions and hence immobilization. ${ }^{2}$ The main disadvantage of adsorption, however, is that the biomolecule may easily desorb from the surface during use.

Covalent attachment of biomolecules to the surface of polymers ensures immobilization without leaching of the biomolecule from the substrate surface. ${ }^{3}$ Covalent attachment of biomolecules to the monomer prior to polymerization has also been reported. ${ }^{4,5}$ This strategy, however, requires lengthy syntheses to produce the monomer or to modify a preformed surface. Because covalent attachment is usually achieved using a linker, the separation of the biomolecule from the polymer backbone can also have disadvantages in terms of signal transduction. ${ }^{6}$

Self-assembly techniques have been investigated for biomolecule immobilization onto various support materials. Layers formed by self-assembly require a polyion to effect biomolecule attachment through strong electrostatic interaction ${ }^{7-9}$ and can result in tightly packed structures that limit diffusion. ${ }^{10}$ Furthermore, careful control of $\mathrm{pH}$ is required to achieve these assemblies and for them to retain stability.

Biomolecules have been trapped within conducting polymers as dopant molecules when the appropriate conditions are met. ${ }^{11,12}$ To function as a dopant for oxidized conducting polymers, anions are required. This restricts the number of biomolecules that can be incorporated using this approach.

We have recently reported the successful vapor phase polymerization of polypyrrole (PPy), poly-terthiophene (PTTh) and poly(3,4-ethylenedioxy thiophene) (PEDT), which allows the incorporation of guest molecules within the polymer matrix via a simple washing step. ${ }^{13,14}$ This procedure obviates the need for covalent attachment of biomolecules and specific charges on either the biomolecule or polymer surface. The maximum possible size of molecules that can be loaded into a conjugated host polymer by this method is yet to be determined, but poly(ethylene glycol) (PEG, Mw $600)$ has been incorporated without difficulty. ${ }^{14}$ In this publication we describe the successful incorporation of the enzyme horseradish peroxidase (HRP, Mw 44,000), a molecule of far greater size than previously incorporated, into a PEDT film. ${ }^{13,14}$ This biomoleculeconducting polymer composite film displayed an amperometric response to hydrogen peroxide, demonstrating promise as a biosensor material.

\footnotetext{
* Electrochemical Society Active Member

z E-mail: junc@uow.edu.au
}

\section{Experimental}

Phosphate buffered saline solution (PBS) was prepared as described in Ref. 2. All other chemicals, 3,4-ethylenedioxythiophene (EDT, Bayer AG), ferric toluenesulfonate [Fe(III) tosylate] (Bayer AG), ethanol (Univar), butanol (Univar), 30\% (v/v) hydrogen peroxide solution (Merck), horseradish peroxidase (HRP) (Sigma), disodium hydrogen orthophosphate anhydrous (APS), potassium dihydrogen orthophosphate (BDH), sodium chloride (Sigma-Aldrich), potassium chloride (Sigma), and hydrochloride acid (Ajax) were used as received.

The polymerization of PEDT by vapor phase polymerization (VPP) was carried out as reported previously. ${ }^{13,14}$ Ferric $p$-toluenesulfonate [Fe(III) tosylate] $(20 \mathrm{wt} \%)$ was coated onto poly(ethylene terephthalate) (PET) foils from a butanol solution. When the coating was almost dry, but before the Fe(III) sulfonate formed crystals, the samples were put into an oven between 50 and $90^{\circ} \mathrm{C}$. After heating for between $30 \mathrm{~s}$ and $3 \mathrm{~min}$, the color of the coating changed to darker yellow, indicating that the solvent had evaporated. The samples were then exposed to 3,4ethylenedioxythiophene (EDT) monomer vapor in the VPP chamber at room temperature. After $1 \mathrm{~h}$, the samples were removed from the chamber with a significant color change from yellow to blue, which indicated the successful polymerization of PEDT. Following air drying for $30 \mathrm{~min}$, these PEDT modified PET foils were washed twice in an ethanol solution containing $0.5 \%$ (w/w) HRP (20 min each). The significant shrinkage of these films during the washing step (from 2174 to $253 \mathrm{~nm}$ measured by profilometer) allows the successful entrapment of molecules within the PEDT films. Rinsing with an ethanol solution containing HRP affects immobilization of the enzyme into the PEDT films. Subsequent to air drying for $30 \mathrm{~min}$, these PEDT/HRP samples were washed in pure ethanol solution for $30 \mathrm{~min}$ to remove the excess HRP from the surface of the PEDT films. No significant change of film thickness is observed in the final rinse in pure ethanol.

UV-visible spectra of PEDT/HRP films were obtained using a Shimadzu UV1601 spectrophotometer, over the range of 310 $1100 \mathrm{~nm}$.

Amperometric sensing tests were performed by using an electrochemical hardware system comprising of an EG\&G PAR 363 potentiostat/galvanostat, a MacLab 400 with Chart v3.5.7/EChem v 1.3.2 software (ADInstruments), and a PC computer. A threeelectrode electrochemical cell was used which comprised a working electrode (PEDT/HRP modified Pt-coated PET), a platinum mesh auxiliary electrode, and an $\mathrm{Ag} / \mathrm{AgCl}$ reference electrode with salt bridge.

Scanning electron microscopy (SEM) elemental mapping was performed using energy dispersive X-ray analysis (EDXA) with a Hitachi S 3000N scanning electron microscope. 
Results and Discussion

The steps used to form the bioactive conducting polymer surface are summarized in Scheme 1. After immobilization of HRP into the

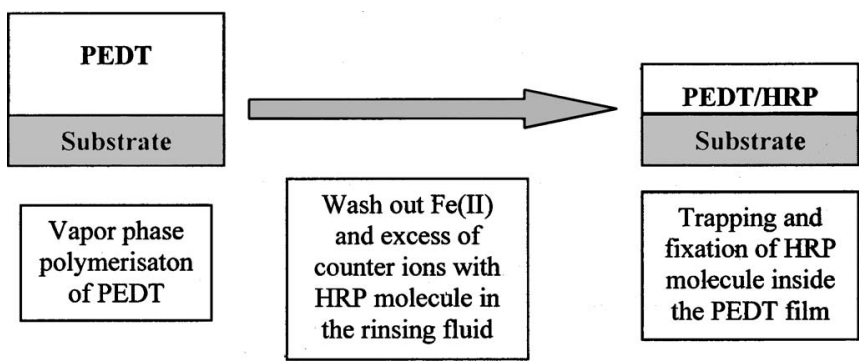

Scheme 1. Loading HRP molecule into the PEDT films.

PEDT, the PEDT/HRP film obtained shows typical redox activity (high capacitance square-like shape) during cyclic voltammetry due to oxidation/reduction of the PEDT in aqueous solution scanned between -0.6 and $+0.6 \mathrm{~V}$.

UV-visible spectroscopy was used to verify incorporation of HRP into the PEDT polymer matrix. Figure 1 presents the UV-vis spectra of the PEDT/HRP film (Fig. 1a), pure PEDT (Fig. 1b), and pure HRP (Fig. 1c). The peak at $317 \mathrm{~nm}$ (peak X) in Fig. 1a can be assigned as a combined contribution of HRP and PEDT, while the peak at $398 \mathrm{~nm}$ (peak Y) is attributed solely to the presence of HRP in the PEDT film. This confirms that the enzyme HRP has been successfully immobilized into the PEDT matrix.

Following the successful immobilization of HRP into the PEDT film, the PEDT/HRP film modified PET electrode was placed in phosphate buffered saline (PBS) solution $(10 \mathrm{~mL}, \mathrm{pH}$ 6.8) as the working electrode in a stirred batch cell. Amperometric experiments were performed potentiostatically at $-100 \mathrm{mV}$ (vs $\mathrm{Ag} / \mathrm{AgCl}$ ). The potential applied during the amperometric test ensures that PEDT will be in the reduced form. The reduced PEDT was necessary as an electron transfer mediator to complete the electron transfer cycle as described in Ref. 15. Hydrogen peroxide $(5 \mathrm{mM})$ was added once the current had reached steady state. Figure 2a shows a typical amperometric response obtained from the PEDT/HRP film upon the addition of $\mathrm{H}_{2} \mathrm{O}_{2}(5 \mathrm{mM})$. It shows that the cathodic current in-

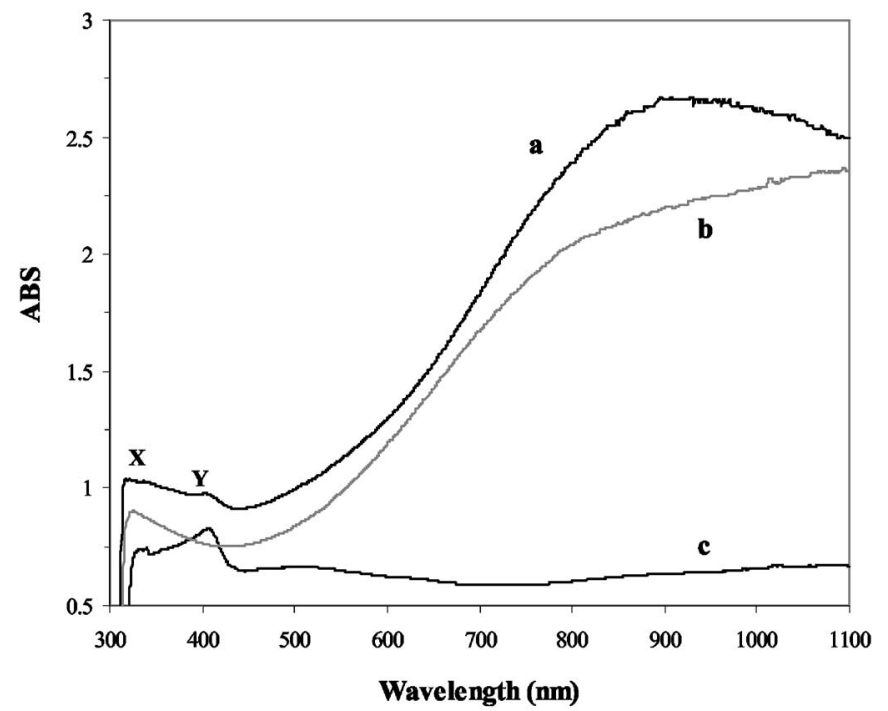

Figure 1. UV-vis spectra of (a) PEDT/HRP, (b) PEDT, and (c) HRP.

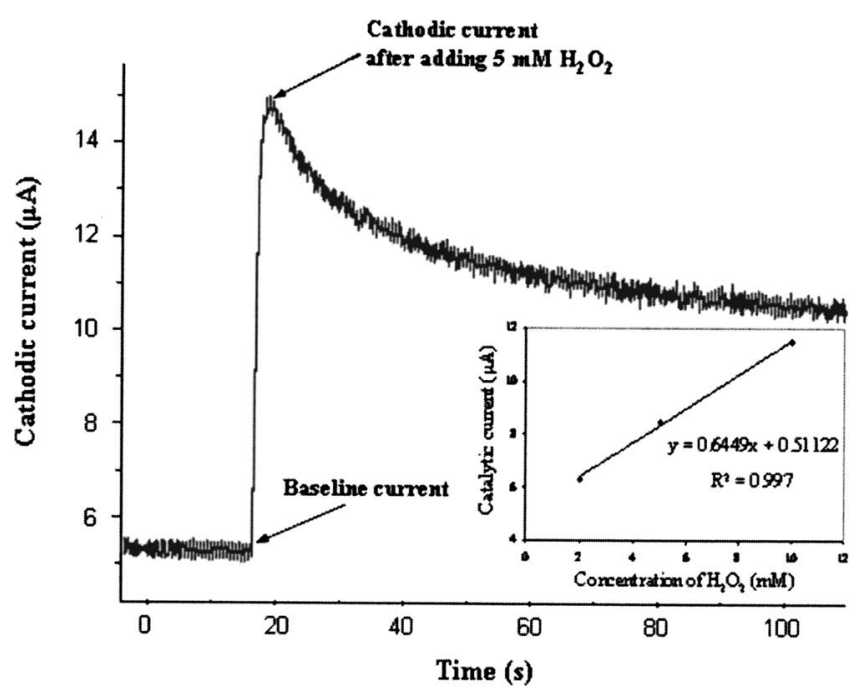

Figure 2. (a) Typical amperometric response of PEDT/HRP biosensor to $\mathrm{H}_{2} \mathrm{O}_{2}$. The applied constant potential was $-0.1 \mathrm{~V}$ (vs $\mathrm{Ag} / \mathrm{AgCl}$ ). " Indicates addition of $\mathrm{H}_{2} \mathrm{O}_{2}(5 \mathrm{mM})$. (b) Catalytic current responses of PEDT/HRP biosensors to various concentrations of $\mathrm{H}_{2} \mathrm{O}_{2}$ in PBS ( $\mathrm{pH}$ 6.4) buffer solution. The applied constant potential was $-0.1 \mathrm{~V}$ (vs $\mathrm{Ag} / \mathrm{AgCl}$ ).

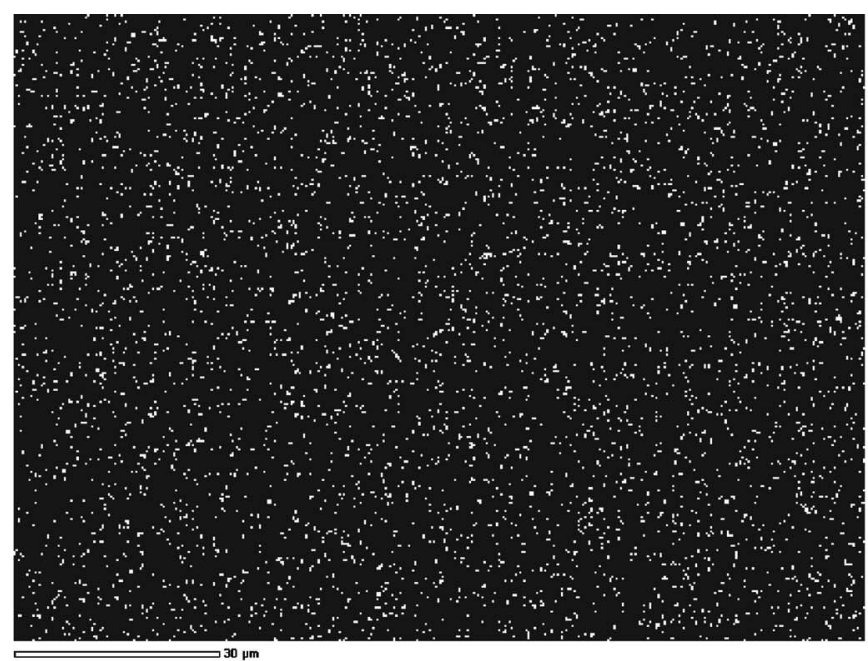

(a)

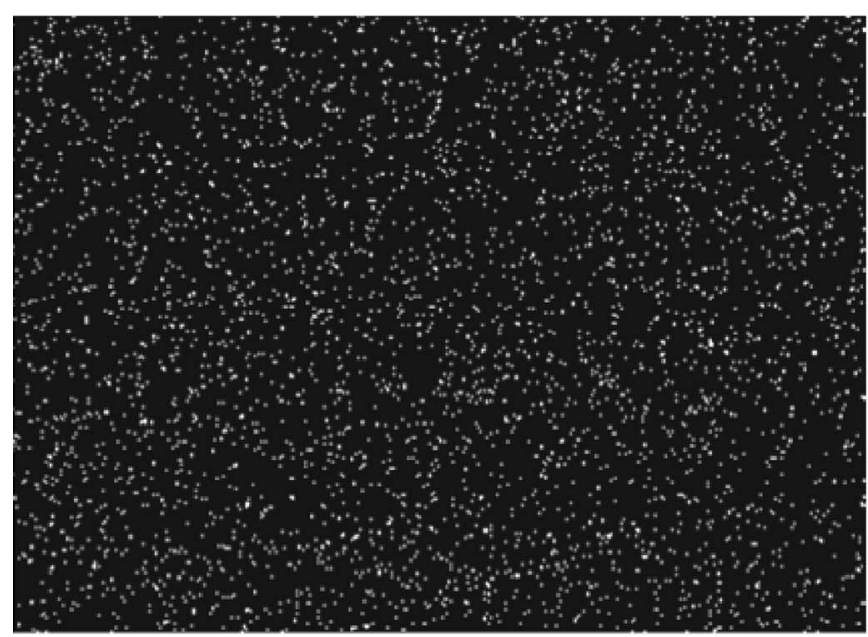

(b)

Figure 3. SEM EDXA mapping images of PEDT/HRP films before (a) and after (b) amperometric biosensing test of $\mathrm{H}_{2} \mathrm{O}_{2}$. 
creased sharply after the addition of $\mathrm{H}_{2} \mathrm{O}_{2}$ with a response time of less than $2 \mathrm{~s}$. The response obtained from the PEDT/HRP film confirms the electrochemical activity of HRP that was immobilized within the PEDT matrix. A high stable amperometric response of the PEDT/HRP sensor (within the difference of 5\%) was observed by repeating the amperometric tests to $\mathrm{H}_{2} \mathrm{O}_{2}$. Various concentrations of $\mathrm{H}_{2} \mathrm{O}_{2}$ in PBS were investigated to test the sensitivity of the PEDT/ HRP films to $\mathrm{H}_{2} \mathrm{O}_{2}$. The catalytic response of PEDT/HRP to various concentrations of $\mathrm{H}_{2} \mathrm{O}_{2}$ is shown in Fig. $2 \mathrm{~b}$ and shows that the catalytic current increased linearly with the increased amounts of $\mathrm{H}_{2} \mathrm{O}_{2}$ added from 2 to $10 \mathrm{mM}$.

The distribution of HRP immobilized within the PEDT film was studied by carrying out SEM-EDXA mapping of the PEDT/HRP films before (Fig. 3a) and after (Fig. 3b) the amperometric biosensing test. The bright spots correspond to Fe sites within the HRP. It was found that the HRP enzyme was uniformly distributed throughout the PEDT film without significant clustering. The SEM-EDXA images of PEDT/HRP obtained before (Fig. 3a) and after (Fig. 3b) exposure to $\mathrm{H}_{2} \mathrm{O}_{2}$ confirm that this structure was retained. Further evidence to confirm this was obtained from elemental analysis which showed a change in the molar ratio of $\operatorname{HRP}(\mathrm{Fe})$ : $\operatorname{EDT}(\mathrm{S})$ from 1:9.1 to $1: 9.5$ (less than $5 \%$ change) after exposure to $\mathrm{H}_{2} \mathrm{O}_{2}$. This drop is attributed to the desorption of surface bound HRP.

This technique offers a novel, simple, and effective immobilization process to load enzyme molecules into conducting polymer films if these enzymes are present in the rinsing fluid used in the post-polymerization washing step. The immobilization process described has great potential to achieve high density enzyme containing polymers for the development of stable biosensors and catalysts.

\section{Conclusions}

This study illustrates the successful immobilization of HRP into a PEDT matrix via the shrinkage phenomenon encountered during the post-polymerization washing step. The PEDT polymeric matrix exhibited a uniform distribution of HRP throughout. This type of biomolecule-conducting polymer film displayed a stable ampero- metric response to hydrogen peroxide; demonstrating its promise as a biosensor material. This kind of sensor also has a high sensitivity to the concentration of hydrogen peroxide. It is hoped that this novel and simple method to load enzyme into conducting polymers will lead to the further development of conducting polymer-based biosensors with improved stability.

\section{Acknowledgment}

We thank the Australian Research Council (ARC) for financial support.

The University of Wollongong assisted in meeting the publication costs of this article.

\section{References}

1. X. Jiang, Q. Xu, S. K. W. Dertinger, A. D. Stroock, T. Fu, and G. M. Whitesides, Anal. Chem., 77, 2338 (2005).

2. A. Morrin, O. Ngamna, A. J. Killard, S. E. Moulton, M. R. Smyth, and G. G. Wallace, Electroanalysis, 17, 423 (2005).

3. A. C. Henry, T. J. Tutt, M. Galloway, Y. Y. Davidson, C. S. McWhorter, S. A. Soper, and R. L. McCarley, Anal. Chem., 72, 5331 (2000).

4. S. Cosnier, B. Galland, C. Gondron, and A. Le Pellec, Electroanalysis, 10, 808 (1998).

5. R. E. Ionescu, C. Gondron, L. A. Gheber, S. Cosnier, and R. S. Marks, Anal. Chem., 76, 6808 (2004).

6. A. I. Minett, J. N. Barisci, and G. G. Wallace, React. Funct. Polym., 53, 217 (2002).

7. Y. Lvov, in Protein Architecture: Interfacing Molecular Assemblies and Immobilisation Technology, Y. Lvov and H. Möhwald, Editors, p. 193, Marcel Dekker, New York (2000).

8. J. F. Rusling and R. J. Forster, J. Colloid Interface Sci., 262, 1 (2003).

9. P. Ugo, L. M. Moretto, G. A. Mazzocchin, P. Guerriero, and C. R. Martin, Electroanalysis, 10, 1168 (1998).

10. Y. Okahata, T. Tsuruta, K. Ijiro, and K. Ariga, Thin Solid Films, 180, 65 (1989)

11. D. Zhou, C. O. Too, and G. G. Wallace, React. Funct. Polym., 39, 19 (1999).

12. V. Misoska, W. E. Price, S. F. Ralph, G. G. Wallace, and N. Ogata, Synth. Met., 123, 279 (2001).

13. B. Winther-Jensen, J. Chen, K. West, and G. G. Wallace, Macromolecules, 37, 5930 (2004).

14. B. Winther-Jensen, J. Chen, K. West, and G. G. Wallace, Polymer, 46, 13, 4664 (2005).

15. E. Iwuoha, D. de Villaverde, N. Garcia, M. R. Smyth, and J. Pingarron, Biosens. Bioelectron., 12, 749 (1997). 